\title{
A Migração dos Sentidos entre Les Bienfaits de la Lune de Charles Baudelaire e Sortilégios da Lua de Oiliam Lanna
}

\author{
The Migration of the Meanings between "Les Bienfaits de la Lune" \\ by Charles Baudelaire and "Sortilégios da Lua" by Oiliam Lanna
}

\section{Antonio Celso Ribeiro}

Universidade Federal do Espírito Santo

antoniocelsoribeiro@gmail.com

Resumo: O presente trabalho objetiva investigar a composição musical Sortilégios da Lua de Oiliam Lanna, sob o ponto de vista do silêncio. Composta para orquestra de cordas em 1998 e profundamente inspirada pela obra Les Bienfaits de la Lune do poeta simbolista francês Charles Baudelaire (1821-1867). O trabalho musical de Lanna foi confrontado com a obra de Baudelaire também a partir do ponto de vista do silêncio. Para tal foi tomado como referência principal o 'silêncio como pré-significação' como instituído por Eni Orlandi, a partir da visão da Análise de Discurso de Linha Francesa. Tratamos também do silêncio musical sob o ponto de vista do pragmatismo e procuramos compreender o papel do mesmo nas obras em questão, investigando as tensões entre paráfrase e polissemia nas duas obras. Por se tratar de uma pesquisa em linguagem não-verbal, usamos como suporte teórico, além dos dispositivos analíticos da Análise de Discurso de Linha Francesa, o conceito de migração de sentidos. Com este estudo pretende-se estabelecer o papel do silêncio como elemento estrutural e coincidente tanto na obra de Baudelaire quanto na de Lanna. A relevância desse trabalho repousa no ineditismo do tratamento dado a uma obra musical puramente instrumental a partir da Análise de Discurso de Linha Francesa inserindo este tipo de formação definitivamente dentro das classificações antes destinadas somente às formas de linguagens verbais.

Palavras-chave: análise musical; poesia; migração de sentidos; silêncio

Abstract: The present study aims to investigate the musical work Sortilégios da Lua [Sortileges of the Moon] by Oiliam Lanna, under the point of view of the silence. Deeply inspired by the work Le Bienfaits de la Lune [The Favors of the Moon] by French symbolist poet Charles Baudelaire (18211867), Lanna's musical work was confronted with Baudelaire's also from the point of view of the silence. For this purpose we took as a main reference the 'silence as pre-significance' as instituted by author Eni Orlandi (2002) inside the view of the French School Discourse Analysis. We also dealt with the musical silence under the point of view of the pragmatism. We attempted to understand the role of silence in such works (Lanna's and Baudelaire's), investigating along the course the tensions between paraphrase and polissemy among them. Once we are dealing with a 
non-verbal language research, besides the analytic devices of the French Discourse Analysis, we also made use as theoretical support the concept of migration of the senses. With this study it intends to establish the paper of the silence as structural and coincident element both in the work of Baudelaire as in the one of Lanna.

Keywords: musical analysis; poetry; migration of meanings; silence

\section{1 - Introdução}

Partindo do pressuposto que a linguagem musical é composta de sons, notas musicais, e silêncios, pausas, e que a linguagem poética é composta de sons, palavras e silêncios, outros sentidos não explicitados pelas palavras, o nosso trabalho irá enfocar e comparar estas duas linguagens de naturezas distintas, mas ao mesmo tempo com muitos elementos em comum.

A música, um dos objetos de estudo desse trabalho, é uma arte que se serve de um sistema de signos sonoros, ou seja, linguagem como meio de expressão, enunciação do pensamento e de ideias. Música então, é linguagem e linguagem não-verbal.

A poesia, o outro objeto de análise e confronto desse artigo, também é uma arte que se serve de um sistema de signos gráficos e verbais, como meio de expressão, enunciação do pensamento e de ideias. Poesia, portanto, é linguagem e linguagem verbal.

Pretendemos confrontar a obra de Baudelaire, em especial o poema Les Bienfaits de la Lune, com a obra musical Sortilégios da Lua de Oiliam Lannaํ. O poema de Baudelaire foi publicado na primeira metade do século XIX, integrando seu livro Le Spleen de Paris. Sortilégios da Lua para orquestra de cordas ${ }^{2}$ foi composta em Belo Horizonte, MG, em 1998, condicionada pela impressão após a leitura do poema de Baudelaire. Nos baseamos, por conseguinte, na transposição ou efeitos do verbal sobre o não-verbal.

\section{2 - O silêncio como pré-significação e a migração dos sentidos}

Estruturalmente, tanto Les Bienfaits de la Lune quanto Sortilégios da Lua seguem os mesmos critérios: abundância de timbres, articulações, dinâmicas, andamentos e vozes polifônicas. Se em Baudelaire Les Bienfaits de la Lune é livre na forma e na métrica, em Sortilégios da Lua, a estrutura rítmica interna, por outro lado, beira o paradoxal: constituída de valores medidos mas com proporções

\footnotetext{
${ }^{1}$ Oiliam Lanna é Professor Adjunto da cadeira de Composição da Escola de Música da UFMG.

${ }^{2}$ A obra musical foi dedicada e gravada em CD pela Orquestra de Câmara SESIMINAS MUSICOOP de Belo Horizonte em 1999.
} 
irregulares (quiálteras, notas pontuadas, síncopas, imbricações ${ }^{3}$, etc), o rigor estrutural destas durações são comprometidas tanto pelas variações de andamento como pela própria estrutura rítmica em si, fazendo com que a mesma soe como livre, imprecisa, incerta, dispondo para a atuação de outros sentidos.

De todos os elementos citados anteriormente, tanto na obra de Baudelaire quanto na obra de Lanna, há um elemento que provoca, em ambas, todas as suas condições de existência: o silêncio. Obviamente, não se trata aqui somente do silêncio acústico, pois não descartamos a possibilidade de sua atuação. Ao contrário, o mesmo acontece de maneira pragmática na obra de Lanna e será abordado nesse trabalho.

Orlandi (2002) nos coloca que o silêncio não é a ausência de sons ou de palavras. Trata-se do silêncio fundador, ou fundante, princípio de toda significação, ou seja, significa o não-dito e o que dá espaço de recuo significante, produzindo as condições para significar. Parte da hipótese de que o silêncio é a própria condição da produção de sentido. Assim ele aparece como o espaço diferencial da significação: lugar que permite à linguagem significar. Então, o silêncio não é o vazio, o sem-sentido; ao contrário, ele é o indício de uma totalidade significativa, o que nos leva à compreensão do vazio da linguagem como um horizonte e não como falta. Não se trata aqui, evidentemente, do silêncio em sua qualidade física, mas do silêncio como sentido, como história (silêncio humano), como matéria significante. É o silêncio que instala o limiar do sentido.

Quando dizemos que há silêncio nas palavras, dizemos que elas são atravessadas de silêncio. Elas produzem silêncio. O silêncio fala por elas. Elas silenciam. Então, o silêncio não está apenas entre as palavras (Orlandi, 2002). As palavras estão cheias de sentido a não se dizer. Ao procurar entender a materialidade simbólica específica do silêncio pôde-se alargar a compreensão da nossa relação com as palavras: não estamos nas palavras para falar delas ou de seus conteúdos, mas para falar com elas. Em nossas reflexões, ao aprofundarmos a compreensão do modo de significar do silêncio, observamos que não há um sujeito tão visível e nem um sentido tão certo, por causa das várias posiçõessujeitos e a migração dos sentidos: o sentido não para, ele muda de caminho. $\mathrm{O}$ silêncio é o reduto do possível, do múltiplo, abre espaço para o que não é um, para o que permite o movimento do sujeito. Onde se situa o trabalho do silêncio? Vejamos: diz-se que sujeito e sentido se constituem ao mesmo tempo. Assim, à errância do sentido, à sua capacidade de migração, corresponde a errância do sujeito que muda de posição, que falha, etc. Então, "todo sentido é efeito de uma refração, todo discurso se funda no equívoco" (Orlandi, 2001). O discurso é efeito

\footnotetext{
${ }^{3}$ A imbricação se apresenta aqui pela união (ligadura) de notas com valores de duração longa com valores de duração curta.
} 
de sentidos entre locutores. O sentido não está alocado em lugar nenhum, mas se produz nas relações: dos sujeitos, dos sentidos, e isto só é possível, já que sujeito e sentido se constituem mutuamente pela sua inscrição no jogo das múltiplas formações discursivas. Compreender o que é efeito de sentidos é compreender a necessidade da ideologia na constituição dos sentidos e dos sujeitos. É da relação regulada historicamente entre as muitas formações discursivas (com seus múltiplos sentidos possíveis que se limitam reciprocamente) que se constituem os diferentes efeitos de sentido entre locutores, e também das suas posiçõessujeito. O limite de uma formação discursiva é o que a distingue de outra formação discursiva mostrando que, segundo Courtine (1982), a formação discursiva é heterogênea em relação a ela mesma, pois já evoca por si o 'outro' sentido que ela não significa. Daí a necessidade do equívoco, do sem-sentido, do sentido outro e do investimento em um sentido. Aí se situa o trabalho do silêncio.

\section{3 - O silêncio como base para a criação}

Para refletirmos melhor sobre a transição da linguagem verbal para a linguagem não-verbal (Orlandi, 1995) e sua consequente recuperação para a (novamente) linguagem verbal, conforme explicitado na Tabela 1, vamos recorrer a uma analogia sobre a importância do silêncio como matéria prima para a criação. Neste caso, teríamos um silêncio funcionando como pré-significação, ou melhor, pré-construído, definido pela Análise do Discurso como o saber discursivo que torna possível todo o dizer.

\begin{tabular}{|l|l|l|l|l|l|l|}
\hline 1 & 2 & 3 & 4 & 5 & 6 & 7 \\
\hline
\end{tabular}

Etapas: ling. verbal $\rightarrow$ transposição para o não-verbal $\rightarrow$ recuperação da verbalização $\rightarrow$ ling. verbal

Tabela 1: transposição da linguagem verbal para a linguagem não-verbal e vice-versa

De acordo com Orlandi (2002), quando se traduz o silêncio com palavras há outro sentido aí, devido à materialidade das palavras. Não há nem uma conceituação em relação ao verbal ou não-verbal. O silêncio simplesmente significa. Mas, vejamos a primeira situação, a da tradução do silêncio com palavras: essa tradução se faz necessária para que possamos compreender o processo de migração dos sentidos na criação de Lanna.

Lanna percorre um longo trajeto desde a leitura de Les Bienfaits de la Lune até a concepção de Sortilégios da Lua. Procuraremos compreender um pouco mais detalhadamente, o processo de migração dos sentidos, desde o primeiro contato com o poema em sua língua original. Pesa na utilização do poema como elemento 
estimulante para a criação de uma obra musical o fato de a poesia baudelairiana em si ser repleta de elementos musicais. Outro fator condicionante também é a musicalidade inerente da língua francesa. Este idioma, cheio de sutilezas e entonações, associado às imagens abundantes do poema formam a combinação ideal para inspirar um tipo de composição mais complexa, sofisticada, igualmente repleta de imagens, sutilezas e entonações.

O processo de migração dos sentidos e a composição propriamente dita se dará em fases distintas, o que não impede que algumas delas possam ocorrer simultaneamente, ou pelo menos aparentemente.

A Tabela 2 possibilita a compreensão deste processo:

\begin{tabular}{|c|c|c|}
\hline & & $\begin{array}{c}\mathbf{1} \\
\text { Baudelaire: } \\
\text { "Les Bienfaits de la Lune" } \\
\text { [elemento estimulante] }\end{array}$ \\
\hline & & $\begin{array}{c}2 \\
\text { Impressão Profunda no Compositor } \\
\text { [Interpretante Dinâmico I] }\end{array}$ \\
\hline & & $\begin{array}{c}3 \\
\text { Concepção Intelectual Sônica: } \\
\text { "Sortilégios da Lua" } \\
\text { [Música em estado mental] }\end{array}$ \\
\hline & & $\begin{array}{c}\mathbf{4} \\
\text { Concretização: grafagem da música (partitura) } \\
\text { Escolha/eleição dos elementos sonoros e ferramentas }\end{array}$ \\
\hline & & $\begin{array}{c}\mathbf{5} \\
\text { Performance [execução ao vivo] } \\
\text { Registro [gravação em mídia digital] }\end{array}$ \\
\hline & & $\begin{array}{c}\mathbf{6} \\
\text { Ouvinte potencial virtual ou real } \\
\text { [Interpretante Dinâmico II] }\end{array}$ \\
\hline & & $\begin{array}{c}7 \\
\text { Análise } \\
\text { Recuperação (ou não) dos } \\
\text { elementos primordiais da } \\
\text { obra de Baudelaire em Lanna }\end{array}$ \\
\hline
\end{tabular}

Tabela 2: processo de migração dos sentidos 
Na etapa 1 (contato com o elemento estimulante), temos o máximo de saturação da linguagem verbal, ou seja, temos aqui palavras que podem explicar outras palavras, gerando metáforas ou, conforme resumiria Lacan, temos então "uma palavra por outra". Entendemos aqui a metáfora não como figura de linguagem, mas como transferência. Ou ainda, retomemos a ideia de metáfora como uma forma de romper com a regularidade que condiciona o aparecimento de estereótipos, conforme diz Pêcheux, com base em Achard (apud Furlanetto 2001, p. 5): As "mesmas palavras significam diferentemente, se as formações discursivas forem diferentes". Como consequência, a transição da etapa 1 para a etapa 2 (impressão profunda no compositor - interpretante dinâmico I), nos aponta para uma mudança de formação discursiva. É entre uma e outra formação discursiva, ou seja, no espaço entre uma e outra que o sujeito se formula (dá forma). O deslocamento em relação a uma outra formação discursiva faz com que o sujeito se (re)posicione, passando de uma primeira ou segunda para uma terceira ou quarta posição. Temos aqui uma oscilação: o sujeito não está plenamente em uma posição e não está plenamente em outra posição no texto. Esta oscilação torna-se evidente no texto.

Para Pêcheux, a formação discursiva é o lugar da estabilidade para o sujeito. E é no deslocamento de sentidos (considerado por Pêcheux como uma transgressão) que o novo pode vir a tomar forma. Se o deslocamento de sentidos somente pode ocorrer entre uma formação discursiva e outra e, considerando que a aprendizagem só pode existir com o deslocamento, concluímos que este lugar (o do deslocamento, entre uma formação discursiva e outra) está repleto de potencialidades, de possíveis, isto é, o nascedouro da criação. Aqui se situa o sujeito autor enquanto criador de obras artísticas ou de linguagens artísticas. Temos então uma ruptura, pois ela é indispensável para que o deslocamento ocorra (Pêcheux, 1988).

Da etapa 3 para as etapas 4 e 5, Lanna, estimulado pela obra de Baudelaire, concebe sônica e mentalmente Sortilégios da Lua. A seguir, textualiza sua concepção transformando as imagens sonoras e mentais em símbolos musicais que vão sendo grafados (anotados) em forma de partitura e que mais tarde serão executados (ao vivo) e registrados (gravados em mídia digital).

Da etapa 5 para a etapa 6, as possibilidades são infinitas para se chegar a um ouvinte real e/ou potencial. Podemos confirmar que o ouvinte potencial tem estado presente desde os estágios iniciais da criação de Sortilégios da Lua. Baseamos este pressuposto na assertiva da Análise do Discurso sobre o papel do leitor potencial.

Vejamos: para a Análise do Discurso, a assunção da autoria implica na inserção do sujeito na cultura, uma posição dele no contexto histórico-social. $\mathrm{O}$ sujeito precisa passar da multiplicidade de representações possíveis para a 
organização dessa dispersão num todo coerente, apresentando-se como autor, responsável pela unidade e coerência do que diz.

Essa representação do sujeito, ou melhor, essa sua função, tem seu polo correspondente que é o leitor. De tal modo isso é assim que se cobra do leitor um modo de leitura especificado pois ele está, como o autor, afetado pela sua inserção no social e na história. O leitor tem sua identidade configurada enquanto tal pelo lugar social em que se define sua leitura, pela qual, aliás, ele é considerado responsável. Isso varia segundo a forma histórica, tal como para a autoria: não se é leitor do mesmo modo na Idade Média e hoje. Entre outras coisas, porque a relação com a interpretação é diferente nas diferentes épocas, assim como também é diferente o modo de constituição do sujeito nos modos como ele se individualiza (se identifica) na relação com as diferentes instituições, em diferentes formações sociais, tomadas na história. Trabalham aí as diferentes formas do confronto do político com o simbólico.

Em outras palavras, quando se cria uma obra de arte (música, poesia, pintura, dança e etc), o autor tem em mente um ouvinte/leitor/espectador potencial - um sujeito capaz de resgatar - com sua memória, com sua bagagem pessoal a essência/intenção da obra em si. Este ouvinte/leitor/espectador potencial deveria de ser capaz de gestos interpretativos no intuito de tornar o sujeito (neste caso o autor) visível (enquanto autor) com suas intenções, objetivos, direção argumentativa. Como nos lembra Orlandi (2002), um sujeito visível é calculável, identificável, controlável. Como autor, o sujeito ao mesmo tempo em que reconhece uma exterioridade à qual ele deve se referir, ele também se remete a sua interioridade, construindo desse modo a sua identidade como autor.

A última etapa (mas não a final), refere-se a um processo estritamente intelectual que compete ao analista de discurso: trata-se da análise da obra de Lanna, pela ótica da Análise do Discurso de Linha Francesa, onde se procura compreender o processo de criação musical (linguagem não-verbal) a partir do estímulo recebido pela leitura de um poema (linguagem verbal), observando a recuperação (ou não) dos elementos primordiais da obra de Baudelaire em Lanna. A Tabela 2 nos mostra o trajeto percorrido entre o início do processo de criação (leitura do poema de Baudelaire), passando pela criação da contraparte musical (Sortilégios da Lua) até chegar na análise propriamente dita (cf. Tabela 1).

Há uma ideologia da comunicação, do apagamento do silêncio, muito pronunciada nas sociedades contemporâneas, que se expressa pela urgência do dizer e pela multidão de linguagens a que estamos submetidos no cotidiano. Ao mesmo tempo, ainda segundo Orlandi, espera-se que esteja produzindo signos visíveis (audíveis) o tempo todo. Temos de estar emitindo sinais sonoros (dizíveis, visíveis) continuamente. Entretanto, parece que não tenha sido sempre assim, segundo a hipótese de que há, na relação com a linguagem, uma 
progressão histórica do silêncio para a verbalização, o que se reflete não só na prática geral da linguagem como no discurso da ciência. Assim, teríamos:

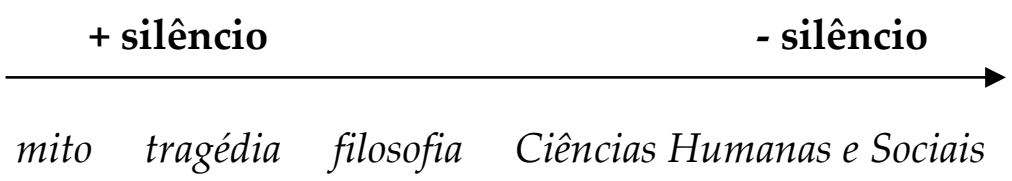

Tabela 3: progressão histórica do silêncio para a verbalização. Fonte: Orlandi (2002)

Explicando: no mito, a significação prescinde da explicitação cabal de seus modos de significar; na tragédia, esta explicitação começa a alargar o seu lugar; na filosofia, se passa para um outro discurso, em que se tematiza vastamente o sentido em sua relação com o ser; este percurso desemboca nas Ciências Humanas e Sociais que se instituem em várias disciplinas diferentes com distintos objetos e discursos diversos para falarem da mesma coisa. Dominado pelas múltiplas metalinguagens, o fato tem de significar nas diferentes explicações que, por sua vez, o povoam de muitos signos. Chegamos então ao exílio do silêncio: do séc. XIX para cá se acelera a produção de linguagens e a contenção do silêncio. As palavras se desdobram indefinidamente em palavras, na maior parte das vezes, ecos do mesmo, sem sair do lugar (repetição iterada do mesmo, as redes parafrásticas, a saturação).

Analogamente, podemos fazer uso dos elementos estruturais da Tabela 3 no intuito de observar (compreender) como o silêncio como pré-significação (aquele saber discursivo que torna possível todo o dizer) funciona no ato de criação de Sortilégios da Lua.

Partiremos dos seguintes pressupostos:

1) quanto maior a quantidade de silêncio, menor o grau de saturação de linguagem verbal (a recíproca é verdadeira);

2) inversamente, quanto maior o grau de concretude do elemento estimulante (Les Bienfaits de la Lune), a saber, as condições de produção que englobam:

Sujeito (quem fala, em que circunstâncias);

Situação estrita (circulação do enunciado, circunstâncias imediatas);

Situação lato (sócio-histórica - ideológica, situação material).

Memória discursiva ou interdiscurso (o já-dito que vai construir o sentido, a paráfrase), proporcionalmente maior será o grau de abstração da obra a ser construída (Sortilégios da Lua), devido à natureza sui generis da linguagem nãoverbal (neste caso, a polissemia, isto é, a possibilidade do sentido vir a ser outro, através do silêncio que faz esta possibilidade - o silêncio e o pré-construído). 
Assim, teríamos:

ETAPAS:

1 - Baudelaire - Les Bienfaits de la Lune

2 - Impressão profunda

3 - Lanna - Sortilégios da Lua

4 - Notação da partitura

5 - Performance \& registro de Sortilégios

6 - Ouvinte potencial

7 - Análise em si da obra Sortilégios

\begin{tabular}{cccccccc}
\multicolumn{2}{c}{ + silêncio } & \multicolumn{4}{c}{ - silêncio } \\
\hline 1 & 2 & 3 & 4 & 5 & 6 & 7
\end{tabular}

Figura 1: (a partir do pressuposto $n^{\circ}$ 1) - progressão do silêncio de Baudelaire para Lanna

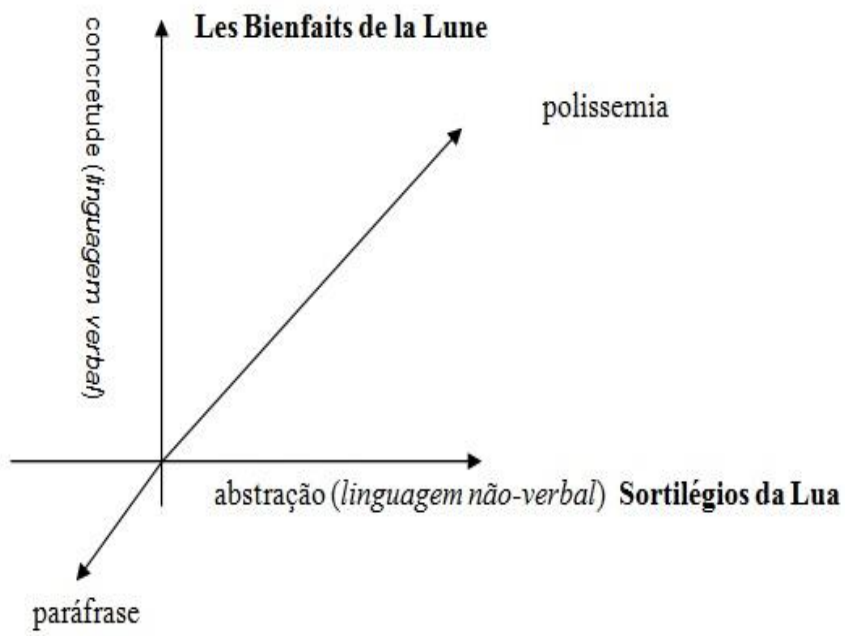

Figura 2: (a partir do pressuposto $\mathrm{n}^{\mathrm{o}}$ 2) - progressão do grau de abstração de Les Bienfaits de la Lune para Sortilégios da Lua

\section{4 - Silêncios discursantes, musicais e pragmáticos: confrontando Baudelaire e Lanna}

É notável a presença de silêncios no poema de Baudelaire: do silêncio fundador - que não há significação possível sem silêncio, ou seja, é a própria condição para a existência do poema; e também do silêncio constitutivo ou antiimplícito, aquele que nos indica que para dizer é preciso não-dizer (uma palavra 
apaga necessariamente as outras). Este silêncio nos remete a outros silêncios, que por sua vez, remetem a outros textos e assim ad infinitum. Segue a íntegra do poema Les Bienfaits de la Lune de Baudelaire (Baudelaire, 2000), traduzido por mim:

A lua, caprichosa, observava pela janela enquanto você estava dormindo em seu berço, e disse a ela mesma: "Aquela criança me agrada".

E então ela suavemente desceu a sua escadaria de nuvens e passou silenciosamente pelas janelas. Então ela se cobriu em cima de você com a submissa ternura de uma mãe, e ela deixou as cores dela em sua face. Seus olhos permaneceram verdes, e suas bochechas extraordinariamente pálidas. Foi enquanto contemplava aquele visitante que seus olhos ficaram tão grotescamente grandes; e ela esmagou sua garganta tão ternamente que você reteve o desejo de chorar para sempre.

Enquanto isso, na expansão de sua alegria, a Lua preencheu todo o quarto como uma atmosfera fosfórica, como um veneno luminoso; e toda aquela luz viva pensou e disse: "Você estará eternamente sujeita à influência de meu beijo. Você será bela à minha maneira. Você amará o que eu amo e os que me amam: a água, as nuvens, o silêncio, e a noite; o mar imenso e verde; a água sem forma e multiforme; o lugar onde você não estará; o amante que você não conhecerá; flores monstruosas; perfumes que o fazem delirante; gatos que desmaiam em pianos, e que gemem como mulheres, com uma voz rouca, suave!".

"E você será amada por meus amantes, cortejados por meus cortesãos. Você será a rainha dos homens de olhos verdes cujas gargantas eu também tenho apertado com minhas carícias noturnas; daqueles que amam o mar, o imenso mar, tumultuoso e verde, a água sem forma e multiforme, o lugar onde eles não estão a mulher que eles não conhecem, flores sinistras que se assemelham aos incensários de uma religião desconhecida, perfumes que perturbam o desejo, e animais selvagens e voluptuosos que são os emblemas da loucura deles".

Eé por isso, maldita criança amada, mimada, que eu estou me deitando agora a seus pés, buscando em toda a sua pessoa o reflexo da formidável Divindade, da deusa-mãe profética, da ama-de-leite que envenena a todos os lunáticos.

No nosso recorte, interessa-nos este silêncio constitutivo que impregna a obra de Baudelaire de magia, mistério, poder e sedução. Flagramos nele o silêncio da antítese e da contradição ao descrever o gesto de opressão da Lua em relação à criança:

"e ela esmagou sua garganta tão ternamente que você reteve o desejo de chorar para sempre"

"Você amará [...] a água sem forma e multiforme"

"[...] com uma voz rouca, suave"

"[...] o lugar onde você não estará"

"[...] o amante que você não conhecerá" 
Flagramos também o silêncio do poder, da vontade outra da Lua em relação ao seu objeto de afeto:

"Você estará eternamente sujeita à influência do meu beijo"

"Você amará o que eu amo e os que me amam"

"E você será amada por meus amantes, cortejados por meus cortesãos"

Por fim, flagramos o silêncio da blasfêmia aduladora na visão do espectador do poema:

“E é por isso, maldita criança amada, que eu estou me deitando agora a seus pés, buscando em toda a sua pessoa o reflexo da formidável Divindade, da deusa-mãe profética, da ama-de-leite que envenena a todos os lunáticos".

Em Les Bienfaits de la Lune, os vários tipos de silêncio já aparecem logo de início, no descarado voyeurismo que a caprichosa Lua faz à criança. Ainda no início, temos aqui o silêncio constitutivo expresso na intenção daquela, que diz a ela mesma o quanto a criança lhe agrada. Diz uma coisa para silenciar outra.

$\mathrm{Na}$ sequência, temos o silêncio daquele (no caso, a Lua) que invade sorrateiramente o quarto de sua vítima, como um ladrão na calada da noite, cobrindo a mesma com seu luar, esmagando a garganta desta tão ternamente a ponto da vítima reter o desejo de chorar para sempre. Aqui o poema nos aponta o silêncio da dominação, do subjugo e da predestinação.

A próxima frase, profética, nos mostra o silêncio que aponta para uma outra função: muda-se a(s) posição(ões) sujeito(s), de amante ("Você amará o que eu amo e os que me amam") para rainha ("Você será a rainha dos homens de olhos verdes $\left.[\ldots]^{\prime \prime}\right)$. Silencia-se uma função para que outra tome o seu lugar.

Por fim, a última frase do poema nos mostra um tipo de silêncio especial - o da ocultação de um personagem sob o outro. Em outras palavras, o silêncio da Lua por detrás da criança - objeto de seu desejo.

Sortilégios da Lua é uma obra repleta de silêncios significantes. Analisemos, pois, o modo de funcionamento destes silêncios. Em uma primeira instância, temos a presença necessária do chamado silêncio pragmático, representado musicalmente pelas figuras negativas de valor ou pausas. Estes elementos são de crucial importância para a estrutura global da obra.

Uma obra musical, grosso modo, é formada pela presença e ausência in tempore de sons. Então, é o jogo de presença e ausência, alternância e concomitância de sons e silêncios que estrutura uma criação musical, fazendo-a discursar em um espaço determinado, garantindo sua existência.

Aprofundemos um pouco mais. Compassos vazios ou parcialmente vazios ocorrem virtualmente em toda obra musical. As pausas são, por conseguinte, uma parte inseparável de qualquer composição. Em níveis mais sutis e modestos, silêncios marcam a transição de uma sentença para a próxima à maneira de uma cesura (isto é, corte ou ruptura). O silêncio também demarca o início e o fim de uma peça musical. 
Em Sortilégios da Lua, este silêncio pragmático apresenta-se, primeiramente, como já falado acima, na forma das figuras negativas de valor ou pausas. Vejamos como estas pausas atuam na obra de Lanna. Todos os fragmentos mostrados a seguir são retirados do manuscrito autógrafo cedido pelo compositor.

Independentemente do caráter universal da pausa, isto é, seus constituintes internos são os mesmos qualquer que seja a sua duração ou função, as pausas nesta obra se apresentam de maneiras distintas, a saber:

1) Em estado de contiguidade, por justaposição:

a) Pausa total, abrangendo de um a até cinco compassos. Aparece em naipes distintos, isto é, nos Violinos I (já no início da peça) e um pouco depois, no naipe dos contrabaixos. Estas pausas maiores funcionam discursivamente de várias maneiras:

a.1) o ainda-não-soado: como já abordado antes, em face da história, o silêncio (marcado aqui pela presença das pausas) significa de várias maneiras, apontando em direção ao futuro, ou seja, o projeto do discurso, a multiplicidade dos sentidos (dá lugar a), enfim, os sons que ainda não temos acesso, mas que já estão em atividade no mundo. No exemplo a seguir, (Fragmento 1) extraído da página inicial do manuscrito autógrafo, temos as pausas do violino I (o primeiro pentagrama de cima para baixo) exemplificando o ainda-não-soado, o que ainda não concebemos e que virá oportunamente se encaixar como uma peça importante neste intricado quebra-cabeças:

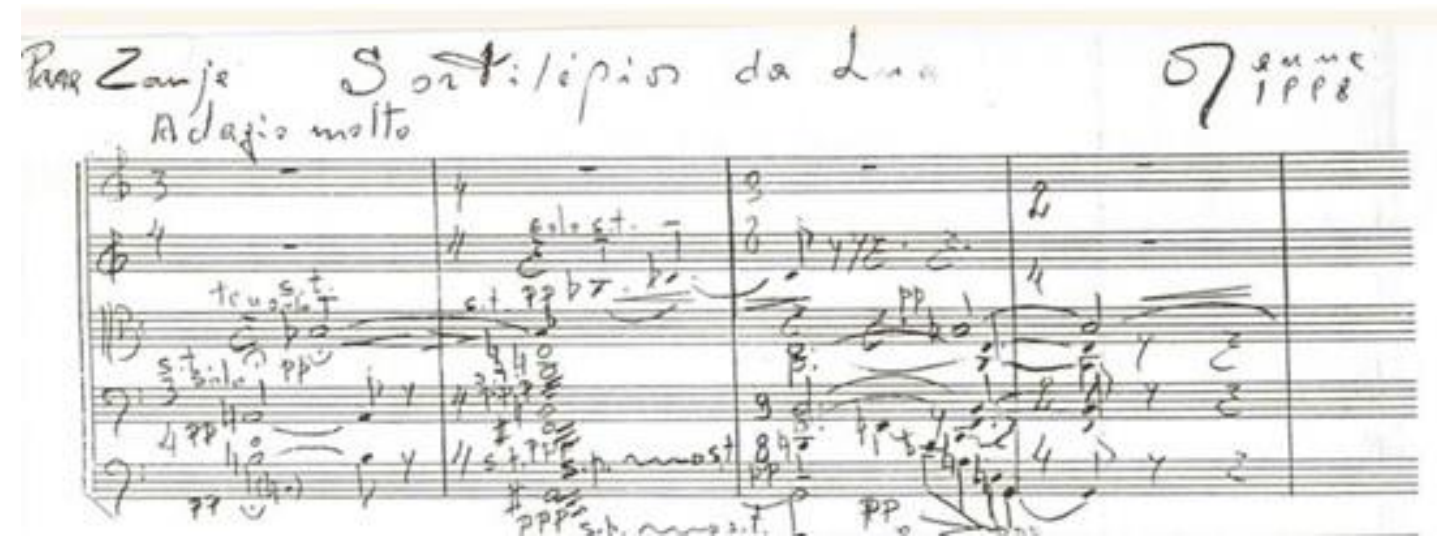

Exemplo 1: compassos 1 a 4 - pausas funcionando como o 'ainda-não-soado'

a.2) o que-já-não-soa-mais: aponta em direção ao passado, ao já-dito que retorna sob a forma de interdiscurso, e que se re-formula, ou seja, aqui temos os sons que já não soam mais, que não temos mais acesso, a não ser pela memória. No exemplo a seguir, extraído do manuscrito autógrafo, temos os três compassos finais da composição. O último compasso em questão pede a extinção dos sons por decrescimento (grafado pelas duas linhas paralelas convergentes [>]) e em 
seguida, a barra dupla anuncia o fim da obra. A partir daí o que se tem são as ressonâncias destas últimas notas que ainda ecoam pelo ambiente, e que serão revisadas pela memória (Exemplo 2):

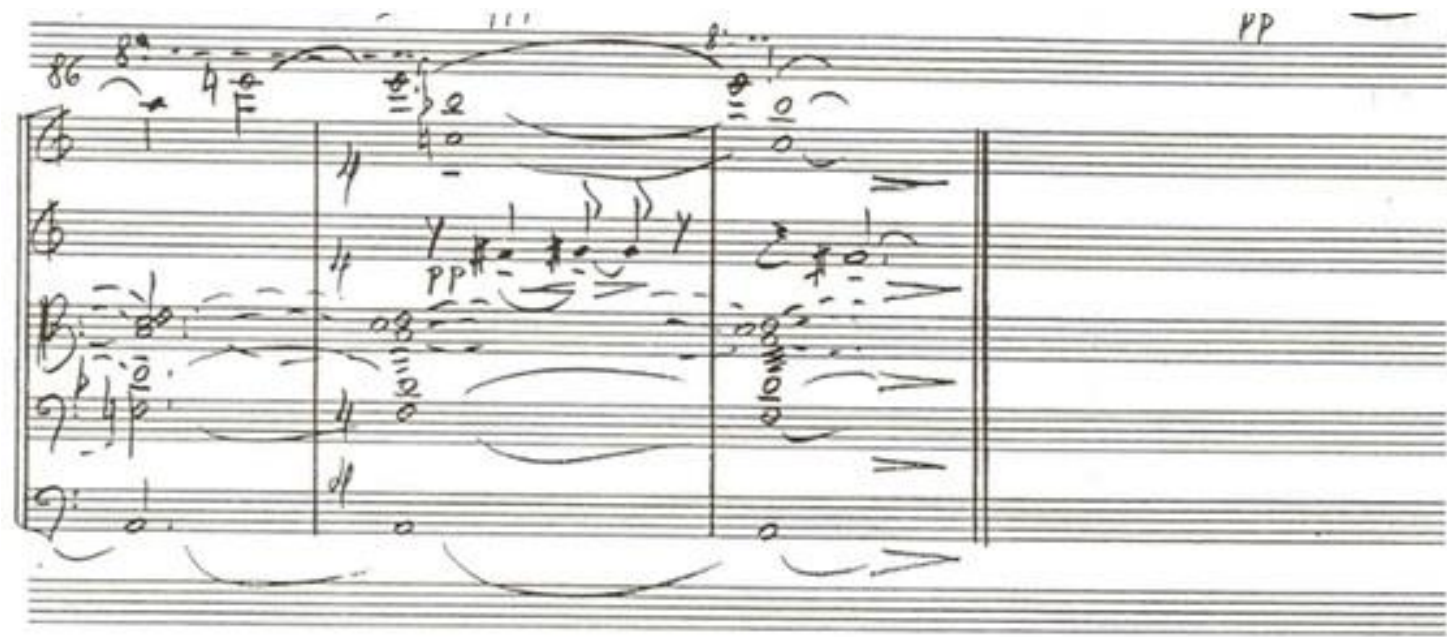

Exemplo 2: compassos 86 a 88 - pausas funcionando como o 'que-já-não-soa-mais'

a.3) marcando etimologicamente a presença do silêncio: silentium - do latim medieval: que está em repouso, (in)ativo. Neste caso, as pausas contribuem para a mudança de densidade da obra, através de efeitos de rarefação. É o que podemos perceber no exemplo abaixo, bem próximo do fim da composição. $\mathrm{O}$ jogo de rarefação presente nos quatro compassos apresentados na nossa exemplificação se faz de maneira quase gradual, atingindo o ápice no terceiro compasso do mesmo, através do solo de um violino do naipe dos violinos I (que por si só já contribui para o aumento da rarefação da sonoridade) em combinação com um acorde das violas. Junta-se a tudo isso as dinâmicas em grau mínimo tanto para o solo quanto para as violas. Os outros naipes estão temporariamente em pausa total (Exemplo 3):

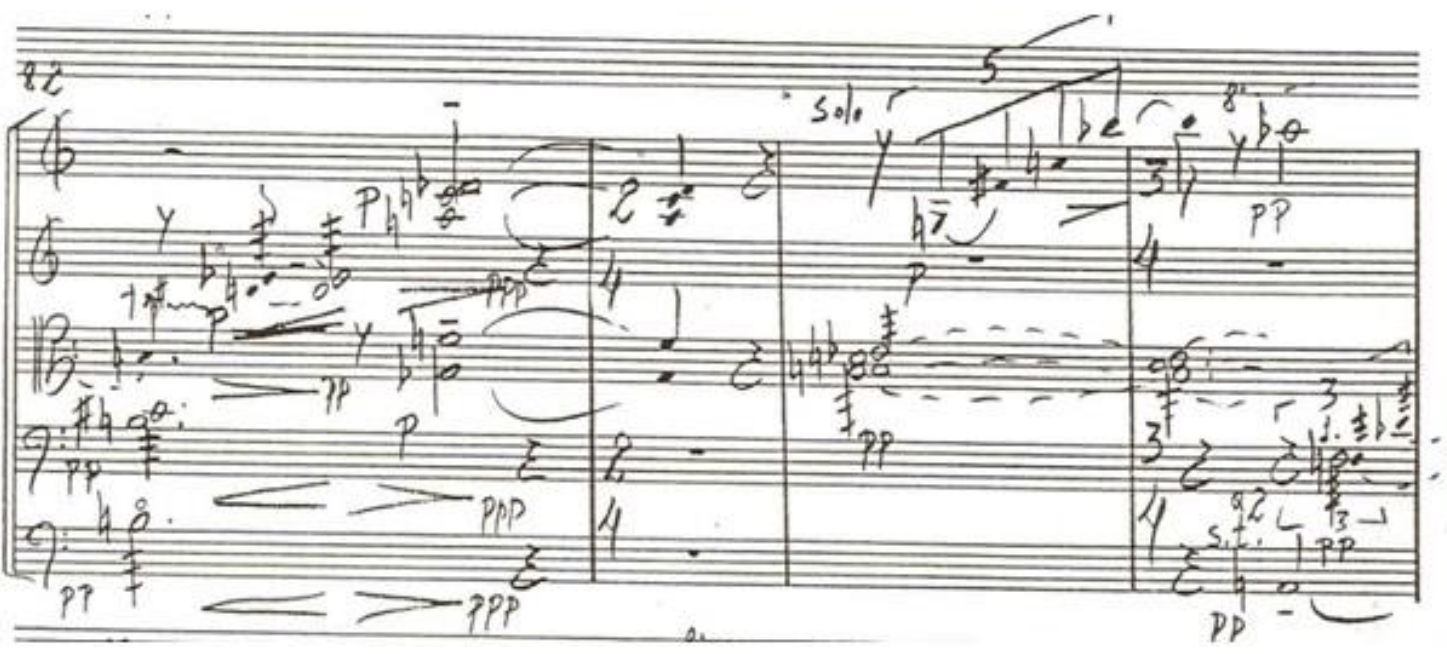

Exemplo 3: compassos 82 a 85 - pausas funcionando como rarefação, marcando a presença do silêncio 
b) As pausas entre um naipe e outro:

b.1) como elemento de marchetaria musical, ou seja, elemento de concatenação melódica e timbrística entre as diferentes vozes. Este dispositivo, exemplificado abaixo, é usado abundantemente em toda a composição. Podemos observar nestes três compassos a alternância entre as pausas (de um naipe para o outro) e os sons articulados num jogo de incrustação sonora e rítmica (Exemplo 4):

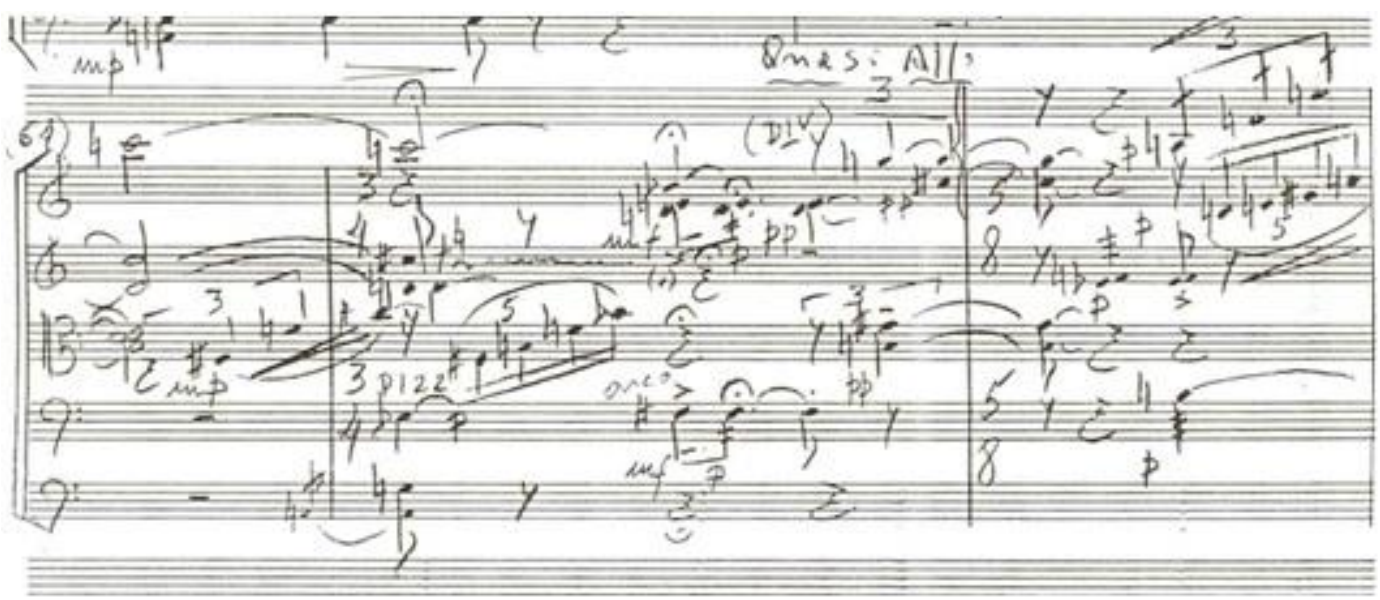

Exemplo 4: compassos 64 a $66^{4}$ - pausas funcionando como marchetaria musical (concatenação tímbrica)

b.2) como elemento espacializador das vozes, criando efeitos de estereofonia. Embora a estereofonia seja um conceito ligado a procedimentos tecnológicos, como aqueles utilizados em estúdios de gravação, visando à separação das fontes sonoras (instrumentos musicais) em canais distintos, as pausas aqui são utilizadas de modo semelhante: propiciando o deslocamento de complexos melódicos entre os naipes, num jogo sutil de perguntas e respostas, criando, consequentemente um efeito de movimento destas fontes sonoras no espaço acústico. Naturalmente, a disposição espacial dos naipes durante a performance também contribuirá sobremaneira para a estereofonia. No exemplo de três compassos abaixo, o jogo de espacialização se dá, no segundo compasso, através dos tremuli nos naipes dos Violinos I, II e violas. Neste caso, o nível sonoro estaria pendendo para uma determinada direção visto que os naipes restantes (violoncelo e contrabaixo) estão silenciados. Tomando emprestado a terminologia referente à estereofonia, poderíamos dizer, grosso modo, que a fonte sonora pendeu para o canal esquerdo (ou canal direito dependendo do ponto de vista). Em outras palavras, trata-se aqui de um jogo complexo de balanço entre as fontes. Por fim, no terceiro e último compasso deste exemplo, temos a atuação do mecanismo da estereofonia, através do método de perguntas e respostas ou,

\footnotetext{
${ }^{4}$ Na verdade, os compassos são 63 a 65, e não 64 a 66 como indica a partitura. Trata-se de um erro do compositor.
} 
em outras palavras, através de fragmentação temática: no último tempo deste compasso há um complexo rítmico-melódico em quintina que se inicia no Violino II e se completa no Violino I (Exemplo 5):

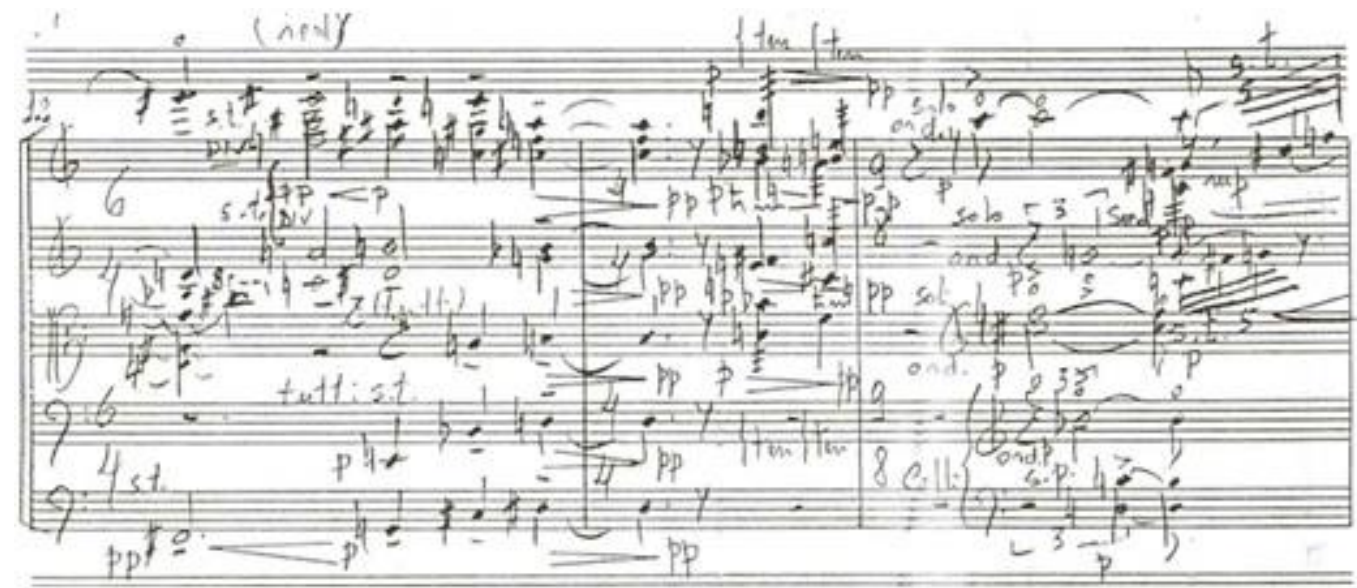

Exemplo 5: compassos 12 a 14. Pausas funcionando como produtoras de estereofonias

b.3) como elemento de ruptura em uma determinada voz ou naipe, concorrendo para a abertura (mudança, migração, deslocamento) de sentidos. Vemos aqui a possibilidade do novo, da (re)significação, da possibilidade dos sentidos poderem vir a serem outros. Expliquemos melhor: a condição da linguagem é a incompletude, pois nem sujeitos nem sentidos estão completos, já feitos, constituídos definitivamente. Sujeitos e sentidos constituem-se e funcionam sob o modo do entremeio, da relação, da falta, do movimento. Essa incompletude atesta a abertura do simbólico, pois a falta é também o lugar do possível. Fazendo uso de analogias, podemos prenunciar que a pausa musical pode perfeitamente funcionar como elemento de articulação para a atuação da polissemia. Mesmo porque, a linguagem não é transparente, e os sentidos não são conteúdos. No exemplo dado a seguir vemos as ressonâncias se extinguirem, fundindo com a pausa (no divisi dos Violinos I e no harmônico emitido pelo naipe dos contrabaixos). Há um esvaziamento súbito que conduz a um outro sentido ideia, estado ou sensação (Exemplo 6): 


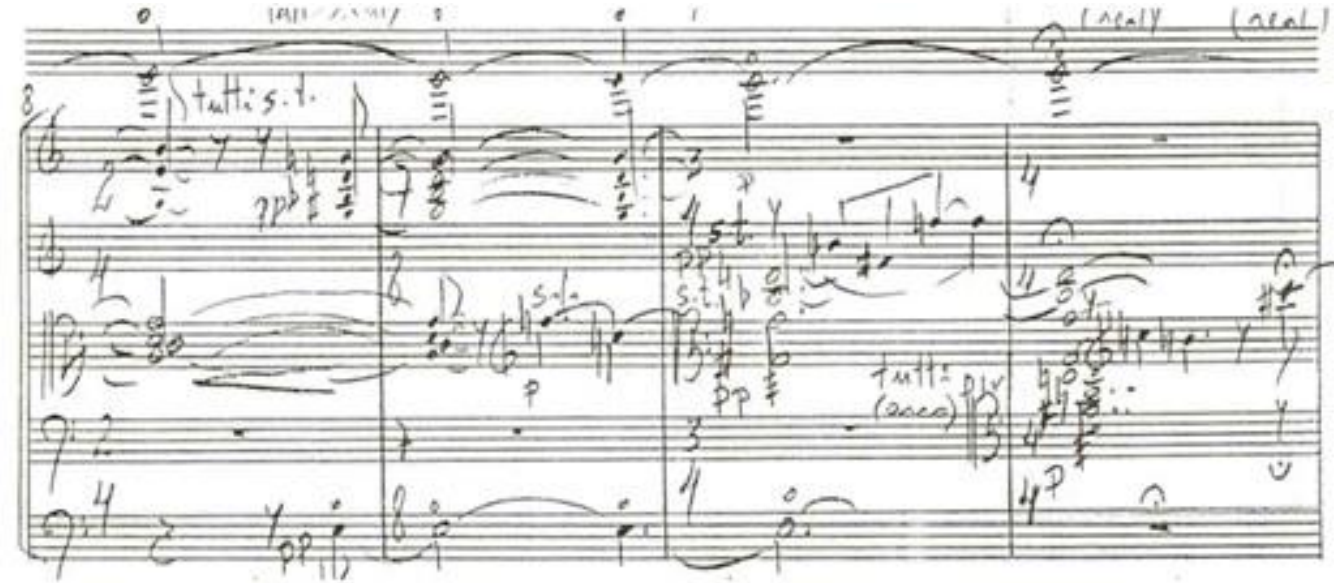

Exemplo 6: compassos 8 a 11 - pausas funcionando como elemento de ruptura, migração de sentidos

b.4) como elemento de repetição para estabilização do sentido musical dentro da obra em si: Orlandi (1999) nos diz que, pela natureza incompleta do sujeito, dos sentidos, da linguagem (do simbólico), ainda que todo sentido se filie a uma rede de constituição, ele pode ser um deslocamento nessa rede. Entretanto, há também injunções à estabilização, bloqueando o movimento significante. Nesse caso, o sentido não flui e o sujeito não se desloca. Ao invés de se fazer um lugar para fazer sentido, ele é pego pelos lugares (dizeres) já estabelecidos, num imaginário em que sua memória não reverbera. Estaciona. Só repete. Partindo dessa assertiva, a autora distingue três formas de repetição, onde duas delas se aplicam à nossa situação:

b.4.1) a repetição empírica (mnemônica) que é a do efeito papagaio, só repete;

b.4.2) a repetição formal (técnica) que é um outro modo de dizer o mesmo;

b.4.3) a repetição, que é a que desloca, a que permite o movimento porque historiciza o dizer e o sujeito, fazendo fluir o discurso, nos seus percursos, trabalhando o equívoco, a falha, atravessando as evidências do imaginário e fazendo o irrealizado irromper no já estabelecido.

Em nosso caso se aplica a segunda e a terceira situação. É evidente que a repetição estabiliza o sentido, e essa estabilização é, de certo modo, necessária, em se tratando de uma obra musical, como elemento de impressão da marca (estilo) de um determinado autor (compositor). Finalmente, o deslocamento que provoca a repetição é o que faz possível as diferentes leituras de uma determinada obra, contribuindo para a multiplicidade de sentidos e mesmo para a sobrevivência da mesma. Por analogia, podemos dizer que as pausas na obra de Lanna funcionam também como elemento de deslocamento e estabilização dos sentidos. Nos exemplos a seguir, vemos a repetição com variantes de um complexo melódico com pausas em quatro momentos distintos da partitura: compasso 15 (pausa de semicolcheia no último quarto de tempo do último tempo 
do compasso); compasso 20 (dobramento de valor da pausa anterior [de semicolcheia para colcheia] mantendo a mesma posição estrutural que no compasso 15); compasso 21 (pausa de colcheia e deslocamento da mesma para o tempo forte do último tempo do compasso [contratempo]) e, compasso 23 (dobramento de valor da pausa anterior [de colcheia para semínima] e deslocamento da mesma para tempo forte do penúltimo tempo do compasso). Vejamos os compassos 15 (Exemplo 7) e 20 (Exemplo 8):

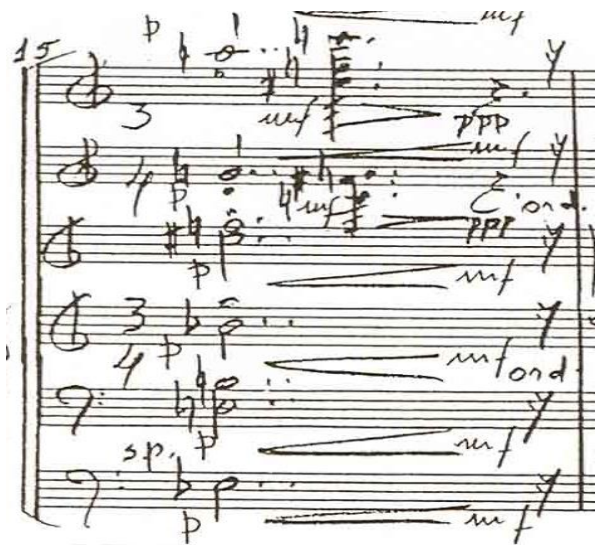

Exemplo 7: compasso 15

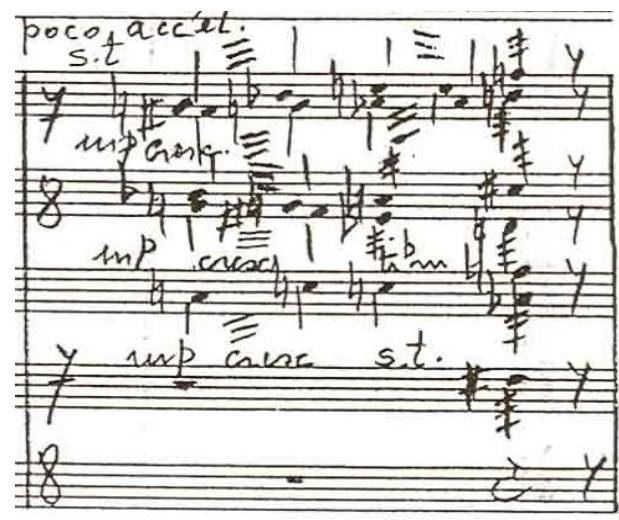

Exemplo 8: compasso 20

Vejamos os compassos 21 (Exemplo 9) e 23 (Exemplo 10):

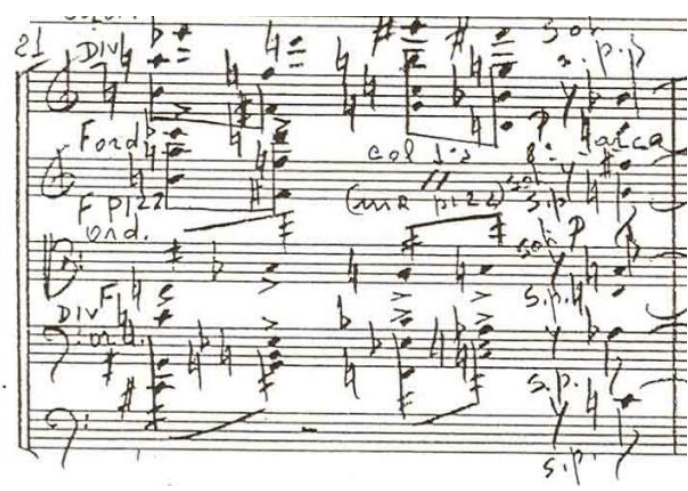

Exemplo 9: compasso 21.

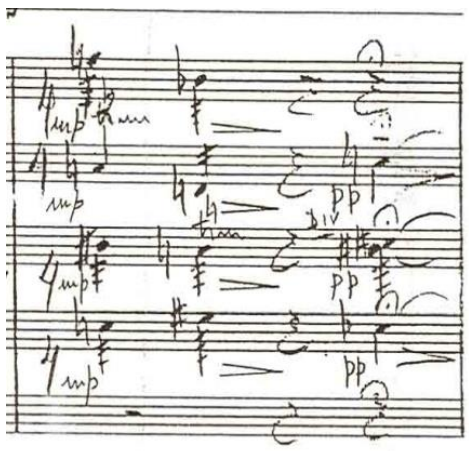

Exemplo 10: compasso 23.

2) Em estado de simultaneidade, por sobreposição:

a) Como elemento indicial: o complexo simultâneo de pausas provoca um recorte, um congelamento do momento. Esse congelamento, inevitavelmente aponta para um estado, um sentimento, uma ideia, uma tensão ou uma sensação. No exemplo dado a seguir, as pausas, em contratempo dão espaço (sentido) para uma única articulação de nota no violoncelo, sutil e quase imperceptível. $\mathrm{O}$ complexo de pausas no final deste compasso é indicial: chama a atenção para a 
mudança de timbre no compasso subsequente, além da mudança de andamento (Exemplo 11):

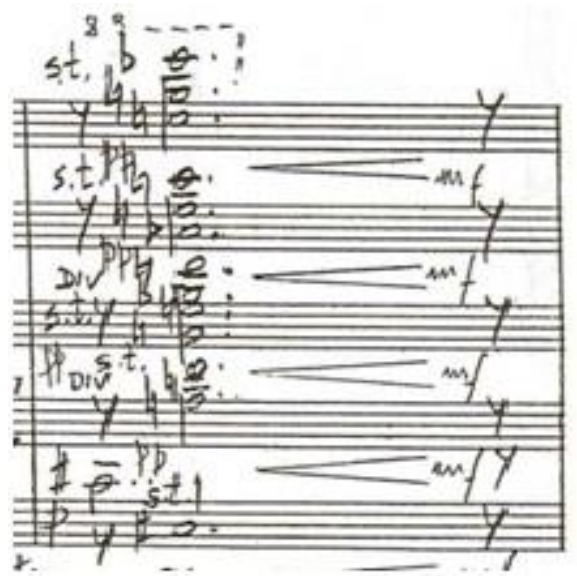

Exemplo 11: compasso 29 - elemento indicial

b) Como elemento de ruptura: da mesma forma que as pausas usadas de modo contíguo, um complexo simultâneo de pausas pode provocar um desvio de sentidos, chamar atenção para algo interno ou externo, bem como criar situações de expectativas e/ou conflito. No exemplo dado a seguir, este elemento é reforçado pelas dinâmicas em fortíssimo (Exemplo 12):

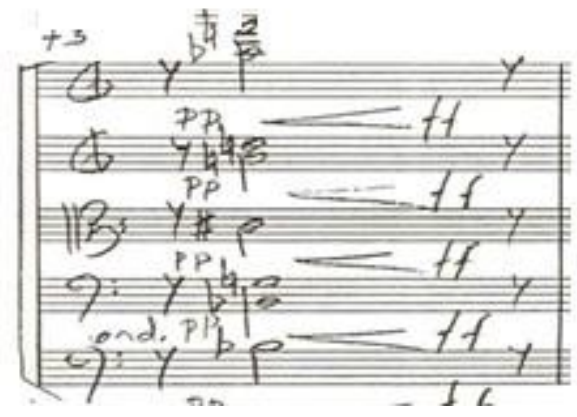

Exemplo 12: compasso 73 - elemento de ruptura

c) Pausa como função de eco: não o eco acústico, a mera repetição (im)parcial de uma frase ou complexo melódico, mas a pausa como espaço e tempo combinados para dar ao ouvinte potencial a capacidade de assimilação daquilo que-já-foi-dito (o que já soou ou acaba de soar). Trabalha diretamente conectada com a memória. No exemplo dado a seguir, o complexo de pausas situadas no final do compasso mostrado recebem a indicação de tenuto, isto é, elas devem ser sustentadas um pouco mais do que as outras pausas justamente para prover o tempo necessário de assimilação do que já soou ou acaba de soar (Exemplo 13): 


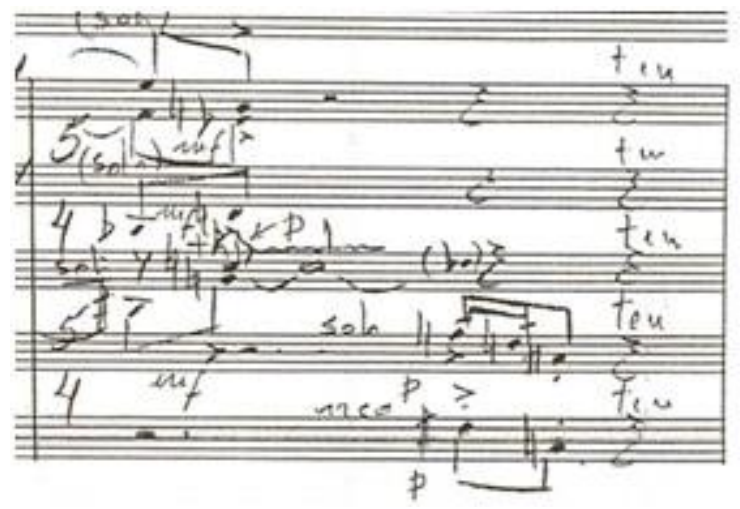

Exemplo 13: compasso 58 - pausas como elemento de assimilação

d) Por fim, mas não por último, a pausa como comentário. Aqui levamos no sentido linguístico da acepção, ou seja, se a definição de comentário passa por parte de uma sentença que veicula informação acerca de outro elemento nela presente, essa veiculação de informação é uma mera possibilidade e pode, eventualmente, apontar para um sentido primeiro (mais proeminente) ou para outros sentidos derivados. É o caso do compasso 70 onde as pausas atuam como comentadoras a ação precedente. Ainda neste compasso, mais especificamente no naipe das violas, a pausa interrompe uma determinada articulação para, em seguida fazê-la soar à guisa de eco. Neste caso, a interrupção funciona como um comentário da ação das violas, reforçando o seu caráter de tensão, clarificando a dissonância do complexo melódico após a referida interrupção no efeito do eco (Exemplo 14):

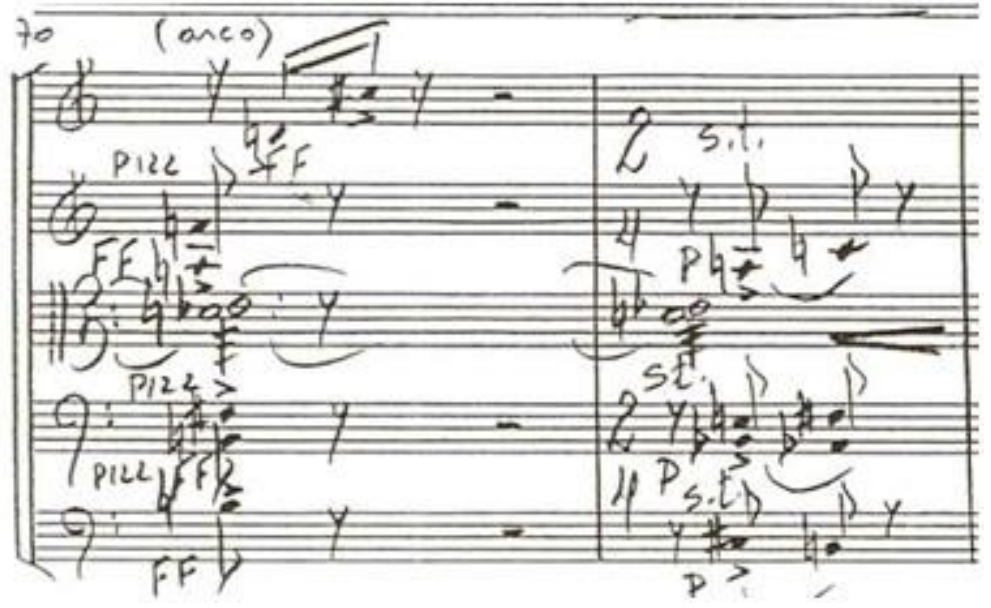

Exemplo 14: compassos 70 e 71 - pausas como comentadoras 


\section{5 - As marcas recuperadas}

Se tomarmos as pausas em sua natureza polissêmica, observaremos que as mesmas também espalham as frases musicais por toda a composição, sugerindo a atmosférica fosfórica do poema, isto é, a Lua adentrando magicamente pelo quarto da criança, suave e misteriosamente. No poema original, estas pausas (silêncios) estão presentes logo no início do poema nas seguintes situações:

A lua observando a criança pela janela;

A lua descendo suavemente a sua escadaria de nuvens;

A lua passando silenciosamente pela janela;

A lua cobrindo a criança com a submissa ternura de uma mãe;

A lua preenchendo o quarto como uma atmosfera fosfórica, como um veneno luminoso.

A lua dominando o seu objeto de desejo.

Se em Baudelaire, a sedução é silente, ou se faz silente entre as palavras e os seus sentidos, permitindo, consequentemente a polissemia, em Lanna, este silêncio, mesmo que, em certa extensão, se apresente de modo pragmático, funciona como elemento estruturador, como leito para as articulações tímbricas que entranham na obra. Vejamos como funciona esta relação:

A poesia é feita de palavras e silêncios. O ritmo dos versos tanto é música como pausa. Dos poetas gregos a Dante Alighieri, são inumeráveis os silêncios que habitam a alta poesia. Há tantos silêncios como formas poéticas. Existe o silêncio romântico, saturado de emoção, que é o silêncio simbolista, através do qual Baudelaire atravessa a natureza, que o contempla, em silêncio, com suas florestas de símbolos. Explicando: Charles Baudelaire, poeta simbolista francês, sensível às transformações que a explosão demográfica estava trazendo para os centros urbanos, via a cidade de Paris como uma floresta de símbolos. Símbolos que lhe lançavam olhares familiares (Santaella, 2000, IX).

Música se faz igualmente com sons e silêncios. Os silêncios (tomados aqui sob o ponto de vista pragmático, ou seja, das pausas) em Sortilégios da Lua se estruturam através de um intricado jogo de aposições com suas justaposições, sobreposições e binarismos. Explicando: o ato de apor elementos em uma criação artística é, no mínimo, o ato de fazer certas escolhas estruturais para a sustentação da mesma. No caso de Sortilégios da Lua, as pausas ou figuras negativas (como também são conhecidas na linguagem técnico-musical) fazem parte deste elemento estrutural e vão funcionar em simbiose com os eventos sonoros. Falando de outro jeito, as pausas não vão atuar somente como meras ausências de som, mas também, como elementos significantes que serão esmiuçados a seguir. 
As ferramentas básicas para dispor o material musical são as já mencionadas justaposições (ferramenta de contiguidade - ato de colocar um elemento após o outro), as sobreposições (ferramenta de simultaneidade - ato de combinar um elemento em cima de outro) e o binarismo - ferramenta de contraste genuinamente dialógica - ato de opor, confrontar, afirmar um elemento em relação a outro. Esta última ferramenta vai trabalhar simultaneamente nos dois níveis: no da justaposição e no da sobreposição.

As justaposições ou ferramentas de contiguidade, marcam presença na composição não somente na articulação dos silêncios (pausas) mas nas articulações tímbricas, dinâmicas, de densidade e de andamento. É certo que estas justaposições trabalham primordialmente por contrastes, assim podemos antecipar que a justaposição é uma ferramenta binarista. Vejamos um pouco mais detalhadamente a justaposição em Sortilégios da Lua:

3.a) Justaposição de silêncios: esta articulação aparece isoladamente em cada naipe da composição. A intercalação de pausas entre as notas musicais funciona por exemplo, para traçar o perfil (contorno) melódico de cada grupo instrumental (a saber: Violinos I, Violinos II, Violas, Violoncelos e Contrabaixos), reforçando, como em toda peça de natureza contrapontística, o caráter de independência de suas partes. A presença de pausas estrategicamente colocadas facilita o câmbio de tessitura de uma determinada estrutura, modificando por assim dizer, o perfil melódico do grupo em questão. No exemplo dado a seguir, a pausa estrategicamente colocada no início do segundo compasso facilita e valoriza a nota aguda em harmônico do violino solista (Exemplo 15):

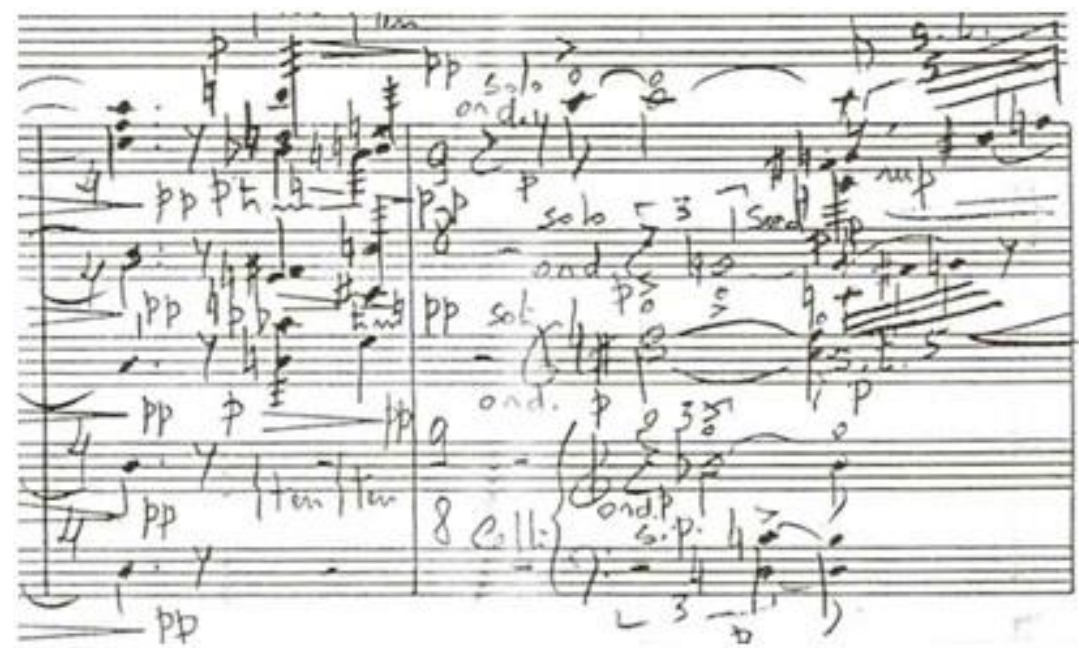

Exemplo 15: compassos 13 e 14 - justaposição de silêncios

3.b) Os elementos tímbricos utilizados por Lanna em Sortilégios da Lua compreendem: notas reais, sons harmônicos (notas agudas), tremuli, notas frotadas, notas em pizzicatti, notas tocadas S.P. (Sul Ponticello, isto é, tocadas bem 
próximo do cavalete, produzindo uma sonoridade vítrea, transparente, devida à ênfase aos harmônicos superiores), notas tocadas S.T. (Sul Tasto, isto é, tocadas em cima do espelho do instrumento, produzindo uma sonoridade próxima da flauta, donde vem o nome alternativo flautando. O som é suave e não focado), e, finalmente, notas tocadas in modo ordinario (ou seja, tocadas no local convencional). No exemplo dado a seguir, vemos algumas destas articulações: tremuli, sons harmônicos e S.T. (Exemplo 16):

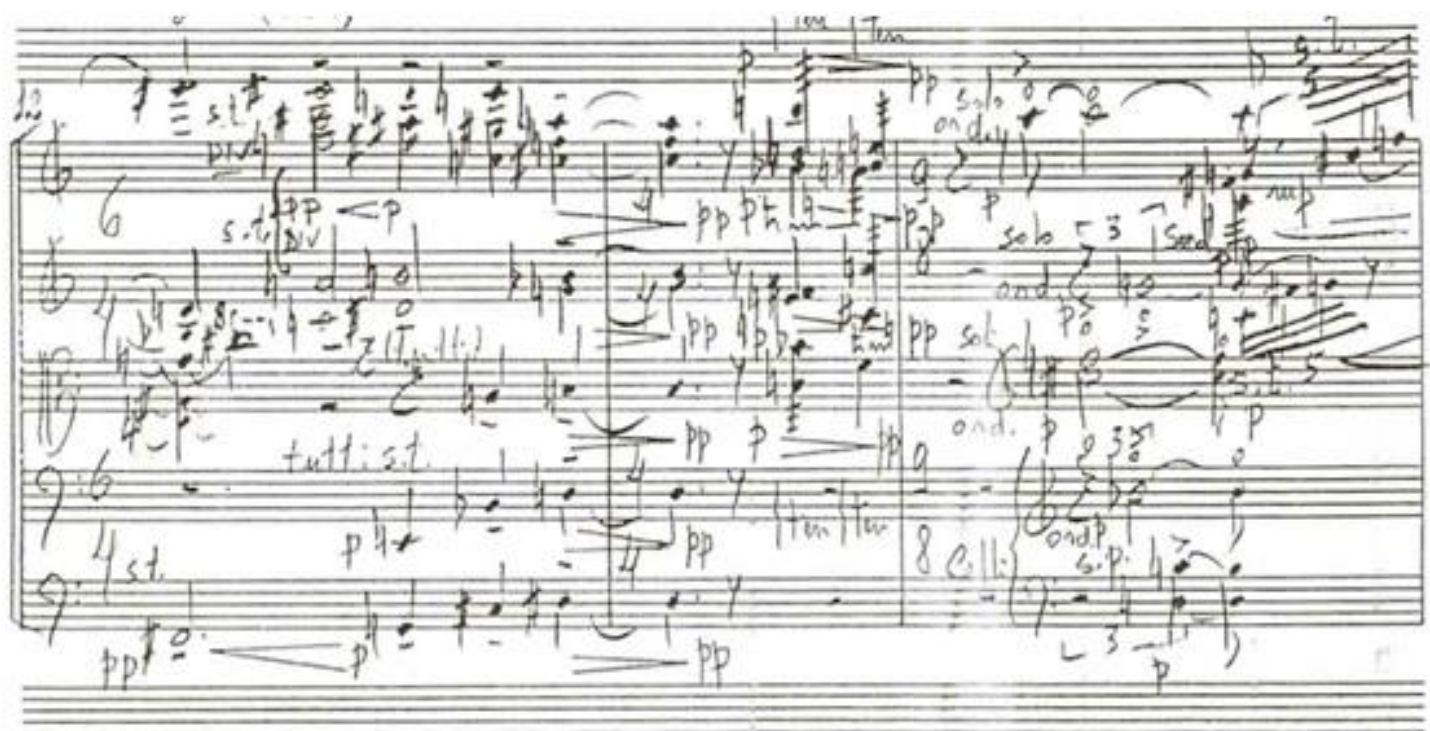

Exemplo 16: compassos 12 a 14 - justaposição de timbres e articulações

4) A justaposição dos elementos de dinâmica estão presentes em toda a obra, virtualmente em cada compasso da mesma. Assim como as pausas ajudam na construção do perfil de cada naipe, a justaposição das dinâmicas também contribuem para a elaboração do mesmo, movendo as fontes sonoras no espaço acústico, por extinção (sons quase inaudíveis) ou por explosão (máximo de intensidade sonora). Nos exemplos dados a seguir, no Exemplo 17, os dois primeiros compassos trabalham com as menores dinâmicas de toda a obra (vide o naipe de contrabaixo).

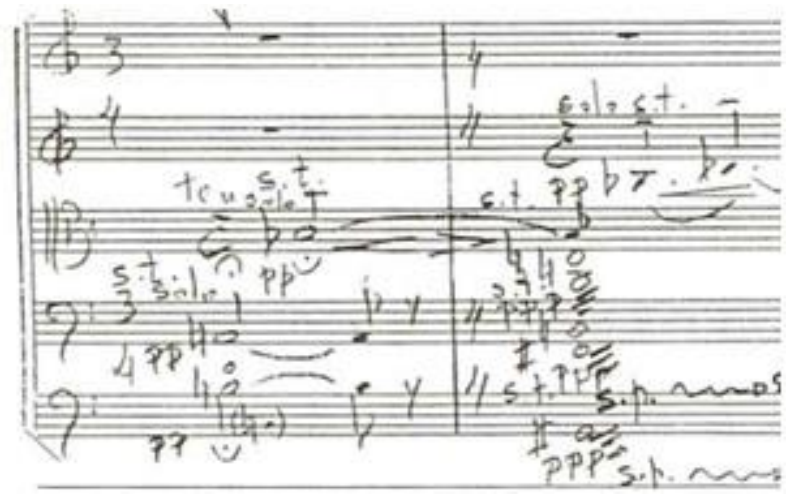

Exemplo 17: compassos 1 e 2. Dinâmicas mínimas 
O Exemplo 18 nos mostra um momento de explosão de dinâmicas (coincidentemente também na parte dos contrabaixos):

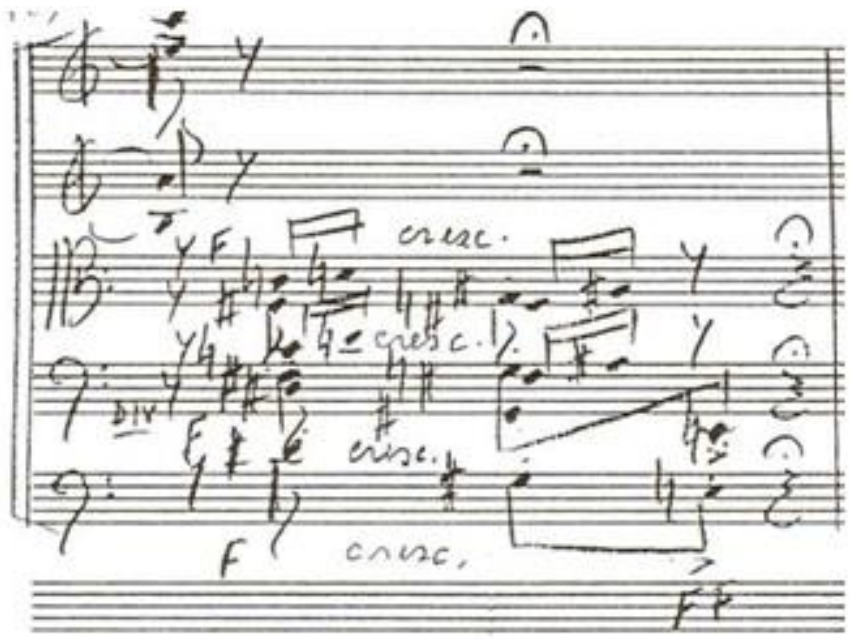

Exemplo18: compasso 46 - explosão de dinâmicas

5) A justaposição de densidades funciona como complemento à justaposição de dinâmicas, contribuindo para a movimentação das fontes sonoras no espaço acústico, simulando um jogo de aproximação e afastamento, densidade e rarefação. No compasso 21 (Exemplo 19), no naipe dos Violinos I, temos o máximo de densidade, com os instrumentos se dividindo em 4 vozes e em dinâmica forte. Logo em seguida, neste mesmo naipe, no compasso 24 e 25 (Exemplo 20), temos o máximo de rarefação, com apenas um violino solista, e em dinâmica suave:

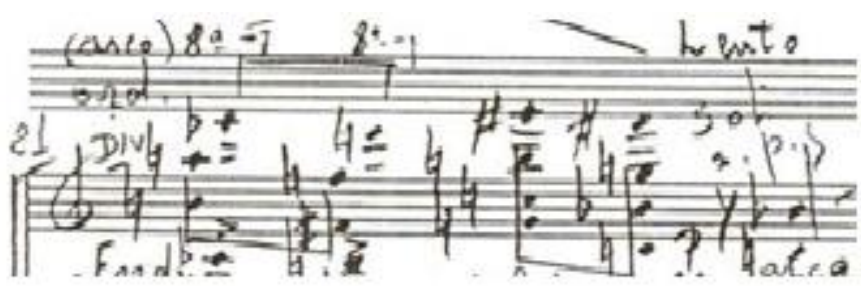

Exemplo 19: compasso 21 - máximo de densidade

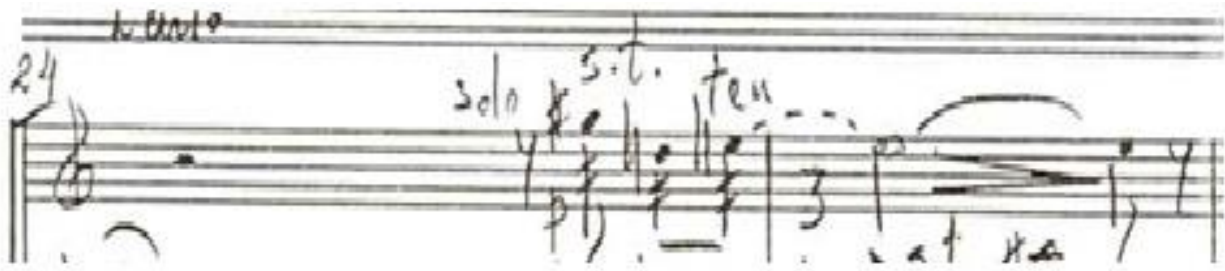

Exemplo 20: compassos 24 e 25 - máximo de rarefação 
6) A justaposição de andamentos concorre para a dramaticidade da obra. Do andamento mais lento logo no início da obra (Adagio molto) ao andamento mais rápido (Quasi Allegro), Lanna faz uso de uma série de andamentos intermediários, além de graduações (accelerandos e ritardandos). Vejamos o quadro completo sequencial dos andamentos utilizados na composição:

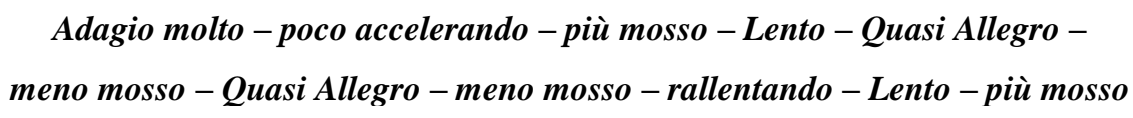

Figura 3: andamentos utilizados na composição de Sortilégios da Lua

Os andamentos seguem uma terminologia italiana desde o século XVII e se tornou convenção mundial. É interessante notar a opção que Lanna faz pelo uso de expressões abstratas para conduzir as variações de tempo em sua obra, ao invés de lançar mão das marcações metronômicas exatas. Ao mesmo tempo, é paradoxal e mesmo contraditório, o uso que Lanna faz de estruturas rítmicas complexas com durações precisas e que serão perturbadas pelas indicações (im)precisas dos andamentos. As expressões: poco accelerando, rallentando, più mosso, e meno mosso, interferem na regularidade do pulso da composição, comprometendo, assim, a sua constância e a validade dos valores rítmicos apresentados na composição. Reconhecemos que esta postura pode, de certa forma, ter vínculos com a fonte original, ou seja, o poema de Baudelaire (Les Bienfaits de la Lune) que inspirou a composição.

Vejamos: o poema Les Bienfaits de la Lune foi publicado no livro Le Spleen de Paris $^{5}$ (também intitulado Les Petits Poèmes en prose) em 1869 por Asselineau e Banville no caderno de uma edição 'definitiva' das obras poéticas e críticas de Baudelaire. Alguns dos poemas foram redigidos nos anos 1850, mas a maior parte foram redigidos entre 1860 e 1865, que era uma época em que Baudelaire quase já não escrevia mais versos. Em suma, o interesse de Baudelaire pelos poemas em prosa começou após a leitura de Gaspard de la nuit' de Aloysius Bertrand (1807-1841). Neste pequeno livro, Bertrand trabalhou uma poesia sem métrica e sem ritmo no sentido da prosódia tradicional, mas delicada e esmerada. Desta maneira, é compreensível o uso que Lanna faz da diversidade de andamentos, bem como da inconstância causada pelas mudanças destes

\footnotetext{
5 Traduzimos literalmente como "O Rondador de Paris".

${ }^{6}$ Gaspard da Noite: livro como uma série de cenas que vão desde a Idade Média até o século XVII. Sub-intitulado "Fantasias à maneira de Rembrandt e Callot", três de seus poemas inspiraram também o compositor francês Maurice Ravel (1875-1937) uma obra homônima para piano solo (1908) em três movimentos a saber: 1- Ondine: um conto sobre um espírito das águas e seu reino; 2 - Gibet: um poema sobre um homem enforcado morrendo lentamente e observando o seu último pôr do sol; e 3 - Scarbo: um pequeno demônio, metade duende e metade fantasma, que faz piruetas, desaparece e amedronta as pessoas em casa.
} 
andamentos nas estruturas rítmicas precisas, já mencionadas acima. Então, os andamentos em Lanna refletem e são refletidos pelo poema de Baudelaire, pois observamos que em Les Bienfaits de la Lune são abundantes as marcas de andamento, através do uso de adjetivos e verbos no pretérito imperfeito, pretérito perfeito simples, presente do indicativo e futuro do presente. Assim, quanto mais distante no passado em direção ao futuro, podemos, por analogia pensar em um tempo lento que aos poucos vai se acelerando, tornando-se mais agitado, dramático e intenso. Esta analogia remonta a uma outra - a do silêncio proposto por Orlandi: quanto mais distante em relação ao passado, maior a presença do silêncio e mais lento o tempo de atuação. E vice-versa.

Os advérbios e adjetivos mostram, com certa clareza, o andamento e o ritmo do poema. Exemplos de advérbios que sugerem um tempo lento: suavemente, silenciosamente, ternamente, eternamente, etc. Exemplos de advérbios que sugerem um tempo rápido: extraordinariamente, grotescamente. Adjetivos: tumultuoso, voluptuosos, etc.

Para a outra ferramenta mencionada anteriormente - a ferramenta de sobreposição ou de simultaneidade - os mecanismos de atuação das pausas são rigorosamente os mesmos já relatados para a ferramenta de justaposição. Portanto, os exemplos utilizados podem perfeitamente servir a esta proposta.

Se há necessidade de se explicitar as diferenças entre as duas ferramentas, poderíamos colocar de uma maneira bastante simplificada: a ferramenta da justaposição ou contigüidade trabalha em um eixo horizontal, linear, que na partitura funcionará da esquerda para direita. Já a ferramenta de sobreposição ou simultaneidade, por outro lado, trabalha em um eixo vertical, também linear e da esquerda para a direita, porém de cima para baixo, ou seja, em blocos.

\section{6 - Baudelaire e Lanna: silêncios entre palavras e silêncios entre notas musicais}

Orlandi (2002) nos lembra que o silêncio não é o vazio, o sem-sentido. Também nos lembra que não está se tratando do silêncio em sua qualidade física, mas do silêncio como sentido, como história (silêncio humano), como matéria significante. Ocorre-nos, neste momento, as palavras de Jacques de Bourbon Busset (1984) que diz:

O silêncio não é a ausência de palavras, ele é o que há entre as palavras, entre as notas da música, entre as linhas, entre os astros, entre os seres. [...] o silêncio é o intervalo pleno de possíveis que separa duas palavras proferidas: a espera, o mais rico e o mais frágil de todos os estados... (Busset apud Orlandi, 2002, p. 70). 
No entanto, reforça que "o silêncio não está apenas entre as palavras. Ele as atravessa. Acontecimento essencial da significação, ele é matéria significante por excelência" (idem, p. 71).

Em suma, estar no sentido com as palavras e estar no sentido sem elas (ou em silêncio), são modos absolutamente distintos de significar, de nos relacionarmos com o mundo, com as coisas, com as pessoas e com nós mesmos. Ressaltando, no entanto, que esta diferença deve ser tomada mesmo como diferença: não se pode traduzir o silêncio em palavras sem modificá-lo, pois a matéria significante do silêncio e a das palavras difere; além disso, o silêncio significa por si mesmo, ou seja, o silêncio não fala, ele significa. Há um ritmo no significar que supõe o movimento entre silêncio e palavras, entre silêncio e linguagens. Observa-se que o estudo do silêncio desloca duas fronteiras: entre o dito e o não-dito, entre o dito e a exterioridade que o determina, fazendo nos confrontar com a questão da natureza histórica da significação. Refletindo sobre o silêncio, compreende-se a necessidade do sentido formulável: se ele é necessário, ele é possível e a garantia desta necessidade é o silêncio, o não-dito, que significa. Os sentidos silenciados migram, produzidos pela necessidade histórica, para outros objetos simbólicos. Para se compreender um discurso, devemos então perguntar sistematicamente o que ele cala.

Desta maneira vemos a possibilidade de o poema de Baudelaire estar povoado de silêncios e sentidos outros, pois sujeito e sentido se constituem ao mesmo tempo. Assim, à errância do sentido, à sua capacidade de migração, corresponde a errância do sujeito que muda de posição, que falha, etc. Podemos, então, nos darmos conta desta migração de sentido, da obra de Baudelaire para obra de Lanna.

Assim surge Sortilégios da Lua: há uma necessidade no sentido, em sua materialidade, que só significa, por exemplo, na música, ou na pintura etc. Não se é pintor, músico, literato, indiferentemente. São diferentes posições do sujeito, são diferentes sentidos que se produzem. A significação é um movimento, um trabalho na história e as diferentes linguagens com suas diferentes matérias significantes são partes constitutivas dessa história. Mais uma vez se reafirma o caráter de incompletude das linguagens. O múltiplo e o incompleto se articulam materialmente: a falha e a pluralidade se tocam e são função do não fechamento do simbólico; e a necessidade das múltiplas linguagens e das distintas matérias significantes é um dos elementos que atestam esse não fechamento. E em Sortilégios da Lua as pausas, ou seja, os silêncios, mesmo que pragmaticamente, vão funcionar como o resultado do silêncio que existe entre as palavras do elemento estimulante, ou seja, Les Bienfaits de la Lune. A partir daí estes silêncios musicais se abrem para novas possibilidades, novas interpretações, novos discursos, lembrando que, sendo a palavra discurso (o que segue seu curso), a 
sua marca comum é a de movimento e o silêncio uma das instâncias em que se efetua o movimento. Ad infinitum.

\section{7 - Considerações Finais}

Nesse trabalho, constatamos o caráter de incompletude da linguagem, seja ela de natureza verbal ou não-verbal. Partindo desta assertiva, verificamos que nem sujeitos nem sentidos estão completos, já feitos, constituídos definitivamente, constituindo-se e funcionando sob o modo do entremeio, da relação, da falta, do movimento. Essa incompletude nos atesta a abertura do simbólico, pois a falta é também o lugar do possível.

Essas considerações nos apontam para o fato de que sujeito e sentido se constituem ao mesmo tempo, pois percebemos que, à errância do sentido, à sua capacidade de migração, corresponde a errância do sujeito que muda de posição, que falha, etc. já que todo sentido é efeito de uma refração e o discurso se funda no equívoco. Então, o sentido se faz movimento e a palavra segue seu curso. Para compreendermos este processo, tomamos a imagem do silêncio como desdobramento: o ponto em que o discurso se desdobra em outras palavras. $\mathrm{O}$ silêncio funciona assim como ponto de fuga em que os sentidos se desdobram. $\mathrm{O}$ silêncio, polissêmico em sua materialidade, nos permite compreender a incompletude na base da interpretação, dos trajetos dos sentidos, dos deslocamentos dos sujeitos, movimento contínuo entre a repetição e diferença.

Assim, se explica a migração de sentidos entre Les Bienfaits de la Lune de Baudelaire e Sortilégios da Lua de Oiliam Lanna.

Entendemos que a significação é um movimento, um trabalho na história e as diferentes linguagens com as suas diferentes matérias significantes são partes constitutivas dessa história. Mais uma vez se reafirma aqui o caráter de incompletude das linguagens, pois o múltiplo e o incompleto se articulam materialmente: a falha e a pluralidade se tocam e são função do não fechamento do simbólico; e a necessidade das múltiplas linguagens e das distintas matérias significantes é um dos elementos que atestam esse não fechamento.

Por esta lógica, notamos que Sortilégios da Lua cumpre seu papel enquanto linguagem, mesmo se tratando de linguagem-não verbal. Semelhantemente, Les Bienfaits de la Lune também cumpre com o seu papel como linguagem, no caso, linguagem verbal.

Partindo das analogias entre os materiais estruturais de ambas as criações, deduzimos que há uma relação de biunivocidade entre as duas composições, com elementos coincidentes ou pelo menos com funções e responsabilidades semelhantes, como podemos observar, por exemplo, na atuação dos timbres, ritmos, pausas, dinâmicas, articulações e sentidos tanto em Les Bienfaits de la Lune 
quanto em Sortilégios da Lua. Temos aqui a possibilidade do sentido sempre vir a ser outro.

Cremos que, pela natureza incompleta do sujeito, dos sentidos, da linguagem (do simbólico), ainda que todo sentido se filie a uma rede de constituição, ele pode ser um deslocamento nessa rede. Mas, como há também injunções à estabilização, o sentido não flui e o sujeito não se desloca, sendo pego pelos lugares (dizeres) já estabelecidos, num imaginário em que a sua memória não reverbera, apenas repete. Notamos que essa repetição, de caráter formal (técnico) - que é um modo de dizer o mesmo, é uma ferramenta indispensável em qualquer composição musical. Trabalhando no nível da paráfrase, observamos a atuação desta ferramenta em Sortilégios da Lua, como elemento amplificador da forma musical, apelando para a memória do ouvinte. Ao mesmo tempo, constatamos a presença de uma outra forma de repetição - a repetição histórica, que é a que desloca, a que permite o movimento porque historiciza o dizer e o sujeito, fazendo fluir o discurso, nos seus percursos, trabalhando o equívoco, a falha, atravessando as evidências do imaginário e fazendo o irrealizado irromper no já estabelecido. Essa forma de repetição nos remete às condições de produção tanto de Les Bienfaits de la Lune quanto de Sortilégios da Lua, trabalhando no nível da polissemia.

Lanna, ao resgatar as condições de produção em Baudelaire, elegeu determinados caminhos, compostos por marcas e propriedades, que nos remetem à época em questão. Em outras palavras, ao ouvir Sortilégios da Lua, vemos que é possível perceber uma memória que alude ao século XIX, em sonoridades e cores harmônicas, climas e atmosferas.

Por outro lado, se o silêncio não é observável, verificamos que ele é interpretável. Sua atuação visível se dá pelo chamado silêncio constitutivo que pertence à própria ordem da produção do sentido e preside qualquer produção de linguagem. Em nosso trabalho notamos que sua atuação se dá ao produzir recortes entre o que se diz e o que não se diz. Em outras palavras, é um efeito de discurso que instala o anti-implícito, onde se diz " $x$ " para não dizer " $y$ ".

Entendemos que o homem está sentenciado a significar, estando irremediavelmente constituído por sua relação com o simbólico, onde tudo tem que fazer sentido, qualquer que ele seja.

Daí a necessidade do nosso trabalho, do regaste das condições de produção de Les Bienfaits de la Lune e de Sortilégios da Lua e suas devidas contribuições para o enriquecimento do patrimônio da humanidade. Daí também a riqueza da interpretação, das posições-sujeitos, da inevitabilidade das redes parafrásticas e polissêmicas, da incompletude da linguagem, do não-fechamento do sentido, da possibilidade do sentido sempre vir a ser outro, do não-dito, do já-dito, etc. 


\section{Referências}

1. Badelaire, Charles. 2000. Le spleen de Paris. Paris: Bibliothèque Gallimard.

2. Bertrand, Aloysius. 2003. Gaspard de la nuit. Trad. José Jeronymo Rivera. Brasilia: Thesaurus.

3. Busset, Jacques de Bourbon. 1984. Le silence et la joie. Corps Ecrit. Paris: P.U.F. 12. In: Orlandi, Eni Pulcinelli. 2002. As formas do silêncio no movimento dos sentidos. 5. ed. Campinas: Unicamp.

4. Courtine, Jean-Jacques. 1982. Définition d'orientations théoriques et méthodologiques en analyse de discours. Philosophiques, v. IX no 2. Paris. In: Orlandi, Eni Pulcinelli. 2002. As formas do silêncio no movimento dos sentidos. 5. ed. Campinas: Unicamp.

5. Furlanetto, Maria Marta. Semântica, estereótipo e memória discursiva. Biblioteca On-line de Ciências da Comunicação. Disponível em <http://www.bocc.ubi.pt $>$. Acesso em 05 de dezembro de 2005.

6. Orlandi, Eni Pulcinelli. 1999. Análise de discurso: princípios e procedimentos. São Paulo: Pontes.

7. 2002. As formas do silêncio no movimento dos sentidos. 5ª ed. Campinas: Editora da Unicamp.

8. . 2001. Discurso e texto: formulação e circulação dos sentidos. São Paulo: Pontes.

9. 1995. Efeitos do verbal sobre o não-verbal. Revista Rua no 1 p. 35-47.

10. Orquestra de Câmara Sesiminas Musicoop. 1999. Sortilégios da lua. Belo Horizonte: Encarte do CD homônimo.

11. Pêcheux, Michel. 1988. Les verités de la palice. Paris: Maspero. Tradução: Semântica e discurso. Campinas: Editora da Unicamp.

12. Santaella, Lucia. 2000. A teoria geral do signo: como a linguagem significa as coisas. São Paulo: Pioneira Thomson. 